\title{
NÅR DET HELE PRESSER SIG PÅ HELE TIDEN
}

Om totalitet, holografi, aura, drømme og meditation.

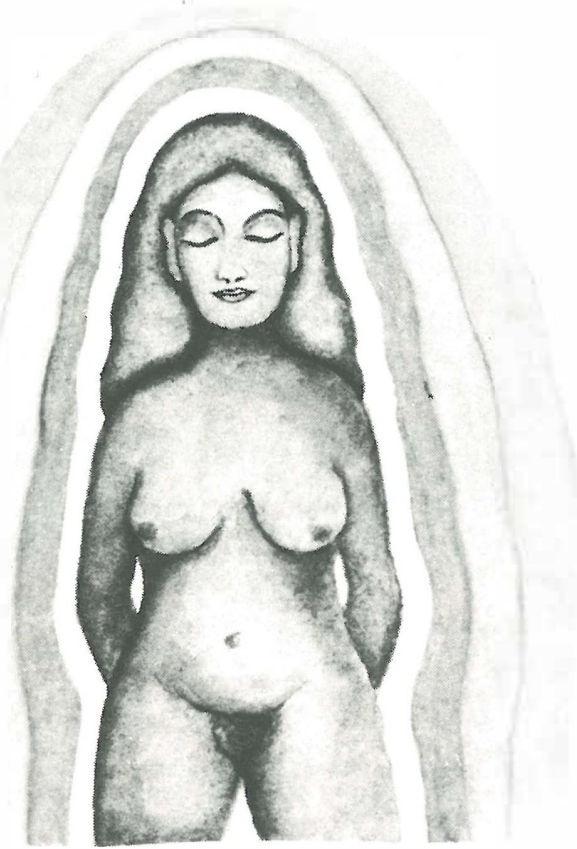

Swami Deva Satyarthi:

Kroppens veje 1-2

Borgens Forlag 1979-82

Jes Bertelsen:

Dybdeps ykologi 1-4

Borgens Forlag 1978-83

Jeg er imod enhver form for alvor. Min hele indstilling er humorens.

Bhagwan Shree Rajneesh

Filosofi i klassisk idealtypisk forstand som encyklopædiske principkontinuerlige totalitetskonceptioner kom efter Hegel ud for noget, der allegorisk-provokativt bedst kan karikeres som et hjertetilfælde af hypokondrisk eller anden neuropatisk karakter. At forandringer og rørelser i de samfundsmæssige sammenhænge begribeligvis har været medvirkende til udløsningen af denne miserable kalamitet, kan i denne kontekst være codylt ligegyldigt. Her skal blot monomanisk og emfatisk pointeres, at den klassiske, metafysisk inficerede, filosofi, forstået som en mere eller mindre mysteriøs-intuitiv “ søgen efter de fundamentale principper til en prætentiøst intenderet universalinterpretation af virkeligehden som virkelighed overhovedet, fik et anfald af pseudo-angina, men levede videre i bédste velgående med de rituelle prækautioner af diætetisk og anden 
kontinent karakter, som enhver hypokonder med respekt for sig selv underkaster sig med masochistisk fryd. De moderne ofte onychofagiske ismer, logier, sofier og tikker, der fulgte $i$ kølvandet af dette epokalt signifikante neurotiske, grænsepsykotiske eller skizofreniforme kollaps, blev med andre ord præget af større eller mindre forsigtighed med hensyn til omnipotente og polymorft perverse interpretationsmodeller, selv om de mere succesrige teoritraditioner efter midten af forrige århundrede ud fra hver sin konceptualiseringsbasis har tilstræbt at attrapere så meget af virkeligheden, som aksiomatikkens eller aksiologiens okkupationsliderlige fangarme overhovedet har kunnet komme i berøring med. Enten dette nu, med eller uden antabus, er sket i form af abstinente, teorikonsistente forsøg på decente palpationer af muligvis latent erogene randzoner eller $i$ form af inkontinente, teoriinkonsistente forsøg på insidiøse tilnærmelser eller kvasi-obskøne befamlinger af virkelighedsområder, der ud fra de pågældende teoriers immanente demarkationsservitutter burde henligge i jomfruelig uberørthed, så har de monokratisk-universalistiske desiderationer som regel været umiskendelige.

Eftersom de moderne humanvidenskabelige teoridannelser på grund af en sig selv ofte ikke transparent aversion af næsten allergisk karakter over for altomfattende forklaringsmodeller og livsanskuelsesfilosofier proklamatorisk hævder eller stiltiende mener at hente deres videnskabelige stringens eller argumentative kohærensbonitet netop ved at renoncere på en totalitetsbegribelse, bliver der i selve udgangspunktet sat en diskrepans mellem virkelighed og begribelighed, der frister til selvoverskridelser. Inkohærens mellem det principielt virkelige og det inden for en given teori principielt begribelige resulterer derfor forståeligt nok ofte i tentative appropriationer af grænseområder og approksimationer i retning af en helhedsforståelse af virkeligheden. Falder en teori for fristelsen til at transcendere sin originære omfangslogiske eller senere principkontinuerligt sanktionerede gyldighedsteoretiske status, risikerer teorien ikke blot at blive flosset i kanten, men også, når den først har perforeret sig selv indefra, som kontra-finalistisk effekt at blive totalt ekskaveret, mens en teori, der i sin selvvalgte käfig-eksistens formår at sidde alle topofobiske og klaustrofobiske alarmsignaler overhørig, til gengæld heller ikke synes at kunne undgå at få problemer med at skærme sig mod den uden for teorien liggende virkelighed. En sådan afskærmning kan i bedste fald ske ved resigneret at overlade den $i$ forhold til teoriens egen kategorialt specifikke approach begribelsestranscendente virkelighed til andre formentligt kategorialt mere adækvate teorier eller ved $i$ værste fald, hvor utroligt det end lyder, at afvise denne virke- 
ligheds teoretisk forpligtende begribelighed overhovedet. Ved på denne måde at afskrive store virkelighedsområder som tilfældighedens og uransagelighedens begrebs-immune og kategori-resistente empiri, afskrives imidlertid, hvor vanvittigt det end kan forekomme, tendentielt og i visse tilfælde partielt-faktuelt også mange virkelighedsområders karakter af virkelighed overhovedet, hvilket sidste desværre ikke kun behøver at være udtryk for fagidiotisk excessiv myopi, men som selvbedragerisk bornerthed strengt taget også kan være symptom på en ikke ufarlig form for psykopatologi.

Spørgsmålet om, hvad der er virkeligt eller uvirkeligt og herunder især hvilke sammenhænge inden for det virkelige, der er virkelige eller uvirkelige, har altid været et af videnskabens og filosofiens mest kritik-receptive points douloureux, selv om mange moderne teorier som proklameret projekttænkning eller ikke vedkendt og ofte ynkeligt camoufleret filosofisk-idealistisk modeltænkning har eksileret eller eskamoteret det ontologiske spørgsmål om virkelighedens egne iboende kognitabilitetskvaliteter. På denne baggrund og på baggrund af de moderne universitært solonfähige humanvidenskabelige teoritraditioners krise, hvor dominerende teorier er kommet til at lide af senil demens og derfor af de endnu mentalt vitale som en art provisorisk ergoterapi søges positionsbestemt i spændingsfeltet mellem modernitet og postmodernitet, er det ud fra en filosofisk og mentalitetshistorisk optik på een gang fascinerende og alarmerende at læse Swami Deva Satyarthis tobindsværk "Kroppens veje" og Jes Bertelsens fire bind "Dybdepsykologi". For mens videnskabsteoretisk velrenomerede skoler spasmodisk forsøger at træde vande med eller uden hjælp af præfikser og andre fiksfakserier, signaliseres der hos Bertelsen og Satyarthi, der vel begge i konventionel humanvidenskabelig forstand må siges at befinde sig på det dybe vand, en erkendelsesoptimisme, der på længere sigt principielt ikke synes at udelukke muligheden for en skønne dag at kunne gå på vandet.

For nu ikke trods disse seduktorisk-propædeutiske diagnosticeringer straks at risikere, at ubefæstede sjæle går i coma af ideosynkrasi over for esoteriske og okkulte dimensioner, må det være opportunt varsomt at bane vejen til en præsentation af den holistisk-holografiske antropologiske model, der er et essentielt struktureringsprincip i Satyarthis næsten encyklopædiske oversigt over alskens alternative helbredelsesmetoder og terapiformer.

Hos Satyarthi, der trods sit ridiculært-ekstravagante kvasi-numinøse nye navn er pæredansk, mødes occidenten og orienten, som det tendenti- 
elt også er tilfældet hos Bertelsen, i orientens faveur. De ekspanderende kommunikationsmuligheder og den hurtige og relativt billige flytrafik med indbygget mulighed for Indientrip og gurutrip synes, som Gita Metha siger det i "Karma Cola", at have udvisket skellet mellem geografi og filosofi, mytologi og historie, hallucination og frelse. Dette rokker imidlertid ikke en tøddel ved den kendsgerning, at man med Satyarthis kompetente og imponerende værk har fàet mulighed for et næsten samlet overblik over terapimarkedet og dermed muligheden for den første instruktive orientering, der er nødvendig, før man eventuelt vælger at kaste sig ud i selvoplevelsens og den personlige erfarings eneste reale mulighed for en evaluering af, hvor megen terapeutisk realitetsgehalt og intellektuelt overbevisende potens, der er i de forskellige harmoniseringsmetoder og udviklingsterapier. På en sådan oplevelsesmæssig og erfaringsmæssig baggrund og netop først på en sådan baggrund vil der selv for en stivnakket vestlig rationalitet være muligt at finde fornuftsmæssige dimensionaliteter i Satyarthis antropologiske model, der indeholder teori-elementer, som man med en smule beredvillighed endog særdeles hurtigt kan følge sig tilskyndet til at acceptere og skyndsomt inkorporere i sin virkelighedsopfattelse. Dette kan eller burde også kunne lade sig gøre uden samtidigt nødvendigvis $i$ een mundfuld at sluge hele læren om menneskets såkaldte esoteriske anatomi og derfor som dele af 80 'ernes i flere henseender udsultede ungdom forslugt også at risikere at få astrologien og reinkarnationsteorien $i$ den gale hals og dermed som yderste konsekvens at blive kvalt $i$ et uliderligt snakkesaligt mixtum compositum af okkultistisk vrøvl og obskuratistisk sludder.

Ren og skær empatisk beredvillighed fra en terapi-uerfaren læsers side behøver Satyarthi imidlertid ikke at lade sig nøjes med at appelere til, eftersom reaktiverede indsigter af næsten arkaisk ælde i menneskets subtile konstitution $i$ form af akupunktur og zoneterapi forlængst har fået en sådan udbredelse og dermed terapeutisk rehabilitering og teoretisk accept, at en totalt skeptisk og apatisk uargumenteret refusering af disse fænomener i dag med rette må imødekommes med den legitime form for kontra-skepsis, der paradoksalt nok ofte er det eneste adækvate modtræk mod gold skepticisme. For Satyarthi, der for øvrigt er uddannet akupunktør, er mennesket i ekstrem forstand en enhedsmæssig helhed. Mennesket bliver af denne orangeklædte Bhagwan-discipel konciperet som homo totus, som det også er tilfældet med Bertelsen, der i parentes bemærket dog nøjes med på diskret afstand af beundre Bhagwan og som derfor heller ikke har noget imod at blive kaldt Jes og være polykromt ekviperet. Da det hele sådan på een gang imidlertid let lissom bare bli- 
ver for meget, må denne antropologiske totalkonception ekspliciteres step by step fra det kendte til det mindre kendte og for nogle måske totalt ukendte; fra det eksoterisk-konventionelle til det esoterisk-kontroversielle.

Mennesket betragtes ud fra Satyarthis filosofisk-antropologiske optik ikke blot som en totalt integreret fysisk helhed, hvor dele af kroppen repræsenterer helheden, pars totalis; men mennesket opfattes først og fremmest i radikal forstand som en psykofysisk helhed og enhed, som psykosomatisk totalitet, sådan som det også er tilfældet i den moderne vestlige medicins psykosomatiske teorier. Spørgsmålet er imidlertid ikke blot, hvilke sammenhænge, der er virksomme og derfor virkelige i mennesket som helhed, men i langt højere grad, hvad der konstituerer disse sammenhængende processers virkelighed, fordi dette spørgsmål i sidste instans er identisk med spørgsmålet om, hvordan man definerer, dvs. afgrænser og bestemmer, mennesket som menneske overhovedet. Mens den traditionelle medicin trods specialiseringens risici og tendensen til at vurdere menneskelige defekter og skavanker ud fra det, der pejorativt betegnes som apparatfejlmodellen, naturligvis også betragter mennesket som en sammenhængende helhed, så gør den totalitetsorienterede terapi dette synspunkt til det absolut altafgørende ud fra det holografiske princip, at hele mennesket er repræsenteret en miniature i partikulære zoner og distinkte sfærer inden for konturerne af det, det udgør og organiserer den menneskelige virkeligheds karakter af virkelighed overhovedet. Det holografiske princip kan utvivlsomt vise sig at blive en sand revolution $i$ den medicinske antropologi, men denne revolution synes dog for intet at regne $i$ forhold til de muligheder, der ligger $i$ en radikal forståelse for, at mennesket som psykosomatisk totalitet realiter er en helhed, hvor det fysiske og det psykiske er reciprokke projektioner og hvor tilgangen til det fysiske gennem det psykiske følgelig er lige så selvfølgelig som tilgangen til det psykiske gennem det fysiske. Satyarthi går imidlértid videre, for ligesom mennesket holografisk kan opfattes som et makrokosmos, hvor i princippet hver enkelt bestanddel er et mikrokosmos, et billede af helheden, således kan mennesket som helhed også opfattes som et mikrokosmos, der afspejler virkeligheden som virkelighed overhovedet, totaliteten som makrokosmos i egentlig forstand. Mens den traditionelle medicin naturligvis i en eller anden forstand også anerkender sammenhængen mellem menneske og milieu spændende fra det sociale til det økologiske, så er den kosmiske antropologi, som Satyarthi i realiteten propagerer, en totalitetskonception, hvor hverken astrologiens eller reinkarnationsteoriens respektive kosmiske og karmiske determinanter 
i princippet er ekskluderet. Det må imidlertid loyalt pointeres, at Satyarthi på dette felt kritik-defensivt holder sig til antydningens tvetydige kunst. Selv om astrologien inddrages $i$ diskussionen, er det ikke på dette i strikte forstand makro-antropologiske niveau, Satyarthi udfolder sig, men på det trods alt mere afgrænsede antropologiske felt, der er indeholdt $i$ teorien om menneskets fem legemer, dvs. teorien om mennesket såkaldte aura.

Både Satyarthi og Bertelsen går som noget helt selvfølgeligt, som en evident præmis, ud fra, at mennesket som psykofysisk totalitet ikke er begrænset af hudens overflade, men tværtimod består af hele fire ekstrakutane strata eller sfærer ud over kroppen $i$ vanlig forstand som det inderste lag. Denne urgamle opfattelse er der al mulig grund til at eksplicitere og diskutere i denne sammenhæng, idet aura-teorien er det punkt, hvor Bertelsen og Satyarthi mødes og kan behandles under eet.

Aura-teorien postulerer, at ethvert objekt er indhyllet $i$ et energifelt, der transcenderer konturen af et objekts i gængs forstand rent fysikalske form. Dette gælder i exceptionel grad mennesket som psykofysisk fænomen, idet auraen her ikke blot fungerer som medium for samspillet med andre mennesker og andre ikke-menneskelige energier, men, ifølge Bertelsen, er karakteriseret ved en struktur, som de esoteriske og okkulte traditioner i princippet er nogenlunde enige om. Mennesket som energifelt består, ifølge disse traditioner, som iriserende lumine scensikke blot af fem lag, men er også strukturet af syv radiationscentre, de såkaldte primær-chakra, der synes at være tilforordnet kirtlerne $i$ det endokrine system. Et menneskes sundhed, harmoni og balance eller mangel på samme skulle kunne konstateres ved at iagttage auraen såvel subjektivt som objektivt. Objektivt skulle dette være muligt ved at benytte en dicyanin-skærm, den såkaldte Kilner-skærm, der blev udviklet $i$ begyndelsen af dette århundrede af den britiske videnskabsmand Walther J. Kilner. Den senere udvikling af det såkaldte Kirlian-fotografi skulle levere endnu en objektiv metode til observation af auraen. Denne fotografiske teknik, der er opkaldt efter det russiske forskerteam, ægteparret Semyon og Valentina Kirlian, er en teknik til højfrekvent elektrofotografering, der stadigvæk udforskes som et både fysiologisk og psykologisk diagnose-instrument. Teknikken, der stadigvæk er stærkt omdiskuteret i den videnskabelige parapsykologiske forskning, selv om den sensationsprægede journalistiske litteratur her tror at have fået et endegyldigt bevis for auraens realeksistens, blev grundlagt i fyrrene og der er her ingen grund til at fortælle den fantastiske geschichte om, hvordan det hele gik til. Det kan man læse om utallige steder. Spørgsmålet 
her er udelukkende, om det på naturvidenskabelige præmisser er muligt at bevise eksistensen of og eventuelt registrere strukturen og konturerne i den esoteriske lære om menneskets auriske energi-udstråling og svaret er, at der ud fra den nyeste videnskabelige litteratur om emnet ikke synes muligt at fremlægge et entydigt og een gang for alle skudsikkert bevis. De objektive indikatorer og kvasi-objektive indikationer, der peger i retning af en eller anden form for eksistens af det energetiske felt, der synes at omgive alle mennesker, er imidlertid så mange, at der ikke engang ud fra en firkantet naturvidenskabelig attitude synes at eksistere klart overbevisende grunde til totalt at afvise teorien om menneskets aura. Hvis auraens realontologiske eksistens var endegyldigt bevist, ville enhver seriøs diskussion naturligvis forstumme, hvilket som bekendt ikke er tilfældet, men udelukkende at ville gøre spørgsmålets besvarelse afhængig af tro eller ikke-tro ville være ren overflade.

Den objektive tilgang til auraen er naturligvis ikke nær så provokerende for en konventionel realitetskonception som den subjektive tilgang, der formidlet af ekstrasensoriske perceptioner clairvoyant omsættes i terapeutisk praksis, som det rent faktisk finder sted for eksempel i form af healing, der praktiseres mere og mere af flere og flere i den terapeutiske subkultur. Selv om princippet fra Kilner-skærmen nu, ifølge Scott Hill, skulle være omsat i fabrikationen af aura-briller, som enhver kan købe, findes der næppe hverken blandt parapsykologer eller på den seriøse del af det spirituelle terapimarked nogen clairvoyant eller psykisk sensitiv person, der i fuld alvor kan anbefale disse briller; men hvorfor pokker skulle man dog også bruge briller, når man udmærket kan se uden eller lære at se uden. Bertelsen, der bruger briller i forbindelse med sit ordinære fysiske syn, lægger ikke skjul på, at han kan se uden briller, dvs. se aura uden aura-briller, begribeligvis.

Hvis nogen på dette tidspunkt på grund af intellektuel konservatisme eller en eller anden form for reaktiv hypersensibilitet over for imponderabilier skulle have fået røde knopper eller brækfornemmelser, kan det da rent parentisk oplyses, at det er et udmærket vomitiv blot at stikke to fingre $i$ halsen. Røde knopper forsvinder ligeledes sikkert sammen med den energi, man bliver af med, når man brækker sig. Ser man bort fra de personer, der allerede er gået helt i stå og som derfor ifølge sagens natur er afskåret fra at stoppe yderligere op, så er der naturligvis altid grund til at standse op over for teorier, der virker obskure eller skurrile; men genuin skepsis er ikke bare en skepsis over for fastslåede sandheder, men også som dialektisk modpol en åbenhed over for nye indsigter og erfaringer. Selv om de færreste humanister i grun- 
den forstår det nye verdensbillede, som de såkaldte eksakte naturvidenskaber har opbygget og stadigvæk bygger på, er det dog de færreste der for alvor betvivler seriøsiteten i de naturvidenskabelige modeller og forskningsstrategier. Gælder det derimod det humanvidenskabelige område går humanister ud fra en abitrær selektionsmekanisme ofte angrebsberedte $i$ forsvarsposition over for fremmedartede eller radikalt nye teorier, som om det her altid kun drejer sig om teorier eller teorier om teorier og aldrig om virkeligheden og de oplevelser og erfaringer, man på utallige måder kan aftvinge 'den virkelighed', vi som mennesker selv er.

Det klassiske skel mellem eksakte og konjekturale videnskaber er forlængst udvisket $i$ en grad, der gør enhver i klassisk forstand natur-videnskabeliggørelse af antropologien $i$ videste forstand til en anakronisme. Der findes ikke universelt gyldige principper til at afgøre, hvad der er virkeligt og uvirkeligt. Det er derfor, selv om det ikke er muligt at fremskaffe nagelfaste videnskabelige kendsgerninger $i$ forbindelse med det livsfelt, der synes at omgive os, næppe udtryk for nogen dristighed overhovedet at antage, at aura-teorien vil indgå i de nye prolegomena til enhver fremtidig antropologi, der skal kunne fremtræde som videnskab. Før et problem bliver anerkendt som noget selvfølgeligt, vil det, som den ulykkelige Schopenhauer har sagt det, altid først blive latterliggjort og derefter angrebet. De fleste humanister er på dette felt knap nok begyndt at grine, i hvert fald ikke offentligt, men det skyldes måske et allerede eksisterende kendskab til nogen eller nogen, der kender nogen, der kan aflæse emotionelle changeringer og diagnosticere fysiske og psykiske disharmonier ud fra energetiske perturbationer og kromofluktuationer i auraen. Auraen er ikke bare noget, nogle få udvalgte kan se, men, avra for laura, noget, mange gennem meditative teknikker vil kunne træne sig op til at se.

Aura-teorien indtager en tilsyneladende relativt beskeden position i Jes Bertelsens teori, som denne er kommet til udtryk i forfatterskabet, hvor det primært er drømme og meditationer, der opstilles som hovedvejene til udforskningen af den menneskelige psykes dybdestruktur. Nu er drømme jo et flygtigt materiale, som man til dommedag kan diskutere meningen med, men allerede for Freud var drømmen en kongevej, en via regia, til det ubevidste. Det er Freud, der rehabiliterer drømmetydningen, der af gode grunde altid har været omgærdet af gætterier og okkult sludder. Bertelsen, hvis væsentligste vestlige inspirationskilde er Jung, bygger ligesom Jung på visse fundamentale principper i den freudske drømme-analyse, men transcendenrer den klassiske psykoanalyses drømme-analytik i flere henseender. På dette punkt er Bertelsen simpelthen 
banebrydende og videns-skabende, hvad enhver kan overbevise sig selv om ved at læse forfatterskabet igennem. Det er imidlertid ikke blot drømme og herunder den geniale teori om det individuatoriske svangerskab, der udgør fundamentet i Bertelsens teori, men, som nævnt, i lige så høj grad meditationens psykologi. Det er heller ikke muligt at gå i enkeltheder på dette felt, hvorfor det blot må nævnes som noget væsentligt, at Bertelsen forsøger at undersøge de forskellige vestlige og østlige meditionsteknikker for ud fra det store materiale at tilvejebringe en gensidig befrugtning. Advarsler mod meditationens kvaler, rædsler og direkte farer for den psykiske stabilitet skorter det ikke på i Bertelsens bøger, der bærer umiskendeligt præg af ikke at være et på boglig lærdom alene baseret intellektuelt skrivebords- og katederarbejde, men et engageret forsøg på at sætte personlige erfaringer fra arbejdet med sig selv og andre ind $i$ nogle teoretiske traditioner og disse traditioners overordnede fælles referencerammer. Hos Bertelsen spores der en så intim relation mellem teori og praksis, at han umuligt kan mistænkes for at bære meninger til torvs udvendigt på skjorten. I modsætning til de universitetsværdige teoriers tendenser til eksistens-eskapistisk verbalisme, er der her tale om eksistentiel substantialisme. Af den grund er det også umuligt her at yde Bertelsen retfærdighed med hensyn til den konkret-indholdsmæssige side af sagen; det ville, som for øvrigt også for Satyarthis vedkommende, ganske enkelt være uoverkommeligt og har da derfor heller aldrig været intentionen.

Med denne reservation in mente må det imidlertid være legitimt afslutningsvis at tage en udlagt rød tråd op og se Bertelsen og Satyarthi en smule i fugleperspektiv for på den måde at ventilere en kritik, der kan og må sættes ind over for de tendenser i tiden, som begge forfattere, hvor forskellige de så end er, må siges at være eksponenter for. For ligesom der ud fra en totalitets-sensitiv optik let kan rettes en kritik mod de moderne og postmoderne humanvidenskabelige teoriers dilemma, der bedst kan karakteriseres som vagabonderende totalitets-eskapisme, så er Bertelsens og Satyarthi, der intet vil have med universiteter at gøre, til gengæld udtryk for den galoperende totalitets-nostalgi, der er blevet så manifest her henimod slutningen af vort århundrede. Den universitets-akademiske berøringsangst over for konjekturale totalitetskonceptioner af næsten uundgåelig eklekticistisk-synkretistisk observans står ofte ikke blot i grel opposition til den enkelte humanistiske forskers intellektuelle, æstetiske og navnlig eksistentielle behov for en helheldsforståelse, men slår også, som for både Satyarthis og Bertelsens 
vedkommende, der begge har hentet deres grundlæggende uddannelse på vore universiteter, over $i$ den fatalt ulykkelige kærlighed til den tabte helhed og enhed, der har været befordrende for den situation, at fragmenterne $\mathrm{i}$ dag er at finde på universiteterne og totalitetskonceptionerne uden for disse. Universiteterne er overhovedet ikke unitive længere, hverken som helheder eller på de enkelte vidensområder. Tværfaglighedsbestræbelserne kan ikke skjule, at det meste af den intellektuelle venstrefløj sammen med andre fløje på og fra humaniora har været, er eller påtænker at gå i terapi, dvs. en i princippet altid totalitetsorienteret form for psykofysisk integrationstræning, der ikke blot har eksistentielle gevinster, men også universitært tabuerede intellektuelle sidegevinster, der udblokker den skizoide spaltning mellem humanisten som docent og privatiserende tænker.

De gesvindte totalitetserobringer, der tilbydes på det mere og mere spirituelt orienterede terapimarked, står i grel modsætning til den akademiske erkendelseserobrings langsommelige og nedslidende etapper, men virker netop derfor enormt tillokkende ikke blot på boglærde, men også på bogdroppere og drop-outs. Der er naturligvis i princippet intet suspekt $i$ at ville gribe og begribe helheden som helhed overhovedet; tværtimod. Filosofi i genuin forstand har altid været karakteriseret ved sin hjemlængsel og filosofi er og bør være nostalgi. Det problematiske er udelukkende, hvordan den filosofisk-nostalgiske stræben udfolder sig, fordi vejen til målet sjældent er forskellig fra målet. Spørgsmålet er derfor, provokerende sat på spidsen, om Satyarthi ikke for hurtigt når fra total orgasme til orgastisk totalitet, selv om det med lidt god vilje er muligt at acceptere den familiaritet, der ligger i at associere et exceptionelt godt knald med big bang. Det vibrerer jo det hele, ikke sandt mere eller mindre konvulsivisk naturligvis, men homogent nok til at levere en måde at begynde at føle sig hjemme på i den ubegribeligt store verden, selv om tantriske dalorgasmer lige så lidt som de mere gængse i sig selv leverer nogen totalitetsbegribelse. Den momentane værensfylde, der med rette kan fables om $i$ forbindelse med vellykkede orgasmer og meditationer, signaliserer en form for væren, der i den grad konvergerer med intethed, at det med hensyn til muligheden for erkendelsesfylde her er vanskeligt at få øje på andet end eleatisk sterilitet. Væren. kan ikke være, pointerer Heidegger, for hvis væren kunne være, ville væren ikke være væren, men et værende. Dybsindigheder på dette niveau er sterile, med mindre de gøres til det de er, nemlig den yderste grænse for et erkendelsesopbyggende arbejde. Det veed både Bertelsen og Sathyarthi, selv om deres bestræbelser for at finde en position i kosmos har 
en tendens til at tildække virkelighedens mangfoldighed og de mangfoldige tilgange til en erkendelse af denne mangfoldighed. Dybdepsykologien og meditationspsykologien har en tendens til at opkaste sig til en enkeltvidenskabelig usurpation af den samlede virkelighed og udforskning af denne. Grundene til dette kan være mange, men måske ligger der et fingerpeg $i$ en tilbageskuen til slutningen af forrige århundrede for at sammenligne stemningen fra dengang med stemningen i dag.

Da det forrige århundrede begyndte at rinde ud, talte man så emfatisk om fin de siècle, at man skulle tro, at det kun var dette århundrede, der virkelig var kommet til vejs ende. Grunden var imidlertid, at fin de siècle-stemningen gik hånd i hånd med en utryg fornemmelse af, at denne afslutning også var afslutningen på den vestlige kulturs blomstringstid, en fin de l'occident. Den angst og ontologiserede usikkerhed, der præger slutningen af vores århundrede er imidlertid langt mere ekstrem end forrige århundredes afslutningsvise angst og uro. Vores fin de siècle er kædet sammen med ikke mindre end angsten for, at der også kan blive tale om en fin du monde. Vi skal ikke bare affinde os med, at en bestemt kulturform kan gå i opløsning, men kapere den horrible tanke, at hele den menneskelige kultur kan gå til grunde. Dette mentalitetshistoriske novum, der ikke nødvendigvis kun sidder i baghovedet, men i hele kroppen, betyder, at det presserende behov for at forstå virkeligheden og mennesket som totalitet ikke kun er udslag af en abstrakt filosofisk-psykologisk helhedslængsel, men som sit historisk ontologiserede korrelat i noget $i$ eminent grad evident omnipræsent, som vi på en eller anden måde må tænke til ende. Enten man f.eks. gør dette $i$ form af et tidsmæssigt altopslugende ekstrovert, kollektivt fredsarbejde med forhåbninger til en global folkelig rejsning eller i form af en tidsophævende, introvert, individuel stræben efter indre fred $i$ form af en erektil kosmisk bevidsthed, så må det være realistisk at se disse tendenser som udslag af det samme, nemlig, at det hele presser sig på hele tiden.

Henry L. Straagaard 